\title{
Response of newly released wheat (Triticum aestivum L.) varieties to different sowing dates under changing climate condition in eastern Uttar Pradesh
}

\author{
D.K. VERMA ${ }^{1}$, SAURABH VERMA*, S.P. GIRI ${ }^{1}$, M.K. PANDEY AND ALOK PANDEY ${ }^{1}$ \\ Krishi Vigyan Kendra, Masodha, FAIZABAD (U.P.) INDIA
}

\begin{abstract}
A field experiment was conducted at Instructional Farm of KVK, Crop Research Station, Masodha of NDUA and T, Faizabad to assess the performance of new wheat varieties under timely sown condition in changing climatic condition. The experiment was laid out in Split Plot Design replicated three times. The treatment comprised of 2 dates of sowing i.e., $15^{\text {th }}$ November and $25^{\text {th }}$ November in main plots and four wheat varieties HD 2967, DBW 39, HD 2733 and PBW 502 in sub plots. The soil of experimental plot was sandy clay loam in texture having low nitrogen $(211.6 \mathrm{~kg} / \mathrm{ha})$ and phosphorus $(11.49 \mathrm{~kg} / \mathrm{ha})$ and medium in potassium $(244.6 \mathrm{~kg} / \mathrm{ha})$ with soil $\mathrm{pH} 7.5$. The early sowing of wheat $\left(15^{\text {th }}\right.$ November $)$ produced significantly higher grains yield $(54.61 \mathrm{q} / \mathrm{ha})$ than delayed sowing $(51.38 \mathrm{q} / \mathrm{ha})$. Earliness in 10 days of sowing of wheat crop in such climatic change conditions influences wheat yield upto 6.29 per cent. The higher yield was due to higher growth and yield attributes influences the growth and development of crops. Among the varieties significantly higher grain yield (53.20 q/ha), straw yield (61.71 q/ha) net return (Rs. 22556.00) and benefit cost ratio (1.86) were obtained with wheat variety DBW 39 over the rest of the three varieties i.e., HD 2967, HD 2733 and PBW 502.
\end{abstract}

Key Words : Wheat, Effective tillers, Ear, 1000 grain weight, Harvest index, B:C ratio

View Point Article : Verma, D.K., Verma, Saurabh, Giri, S.P., Pandey, M.K. and Pandey, Alok (2016). Response of newly released wheat (Triticum aestivum L.) varieties to different sowing dates under changing climate condition in eastern Uttar Pradesh. Internat. J. agric. Sci., 12 (2) : 199-202, DOI:10.15740/HAS/IJAS/12.2/199-202.

Article History : Received : 01.02.2016; Revised : 10.02.2016; Accepted : 13.04.2016

\footnotetext{
* Author for correspondence:

${ }^{1}$ Crop Research Station, Masodha, FAIZABAD (U.P.) INDIA
} 